\title{
Biographical Dictionary of Civil Engineers in Great Britain and Ireland
}

Volume 3: 1890-1920 


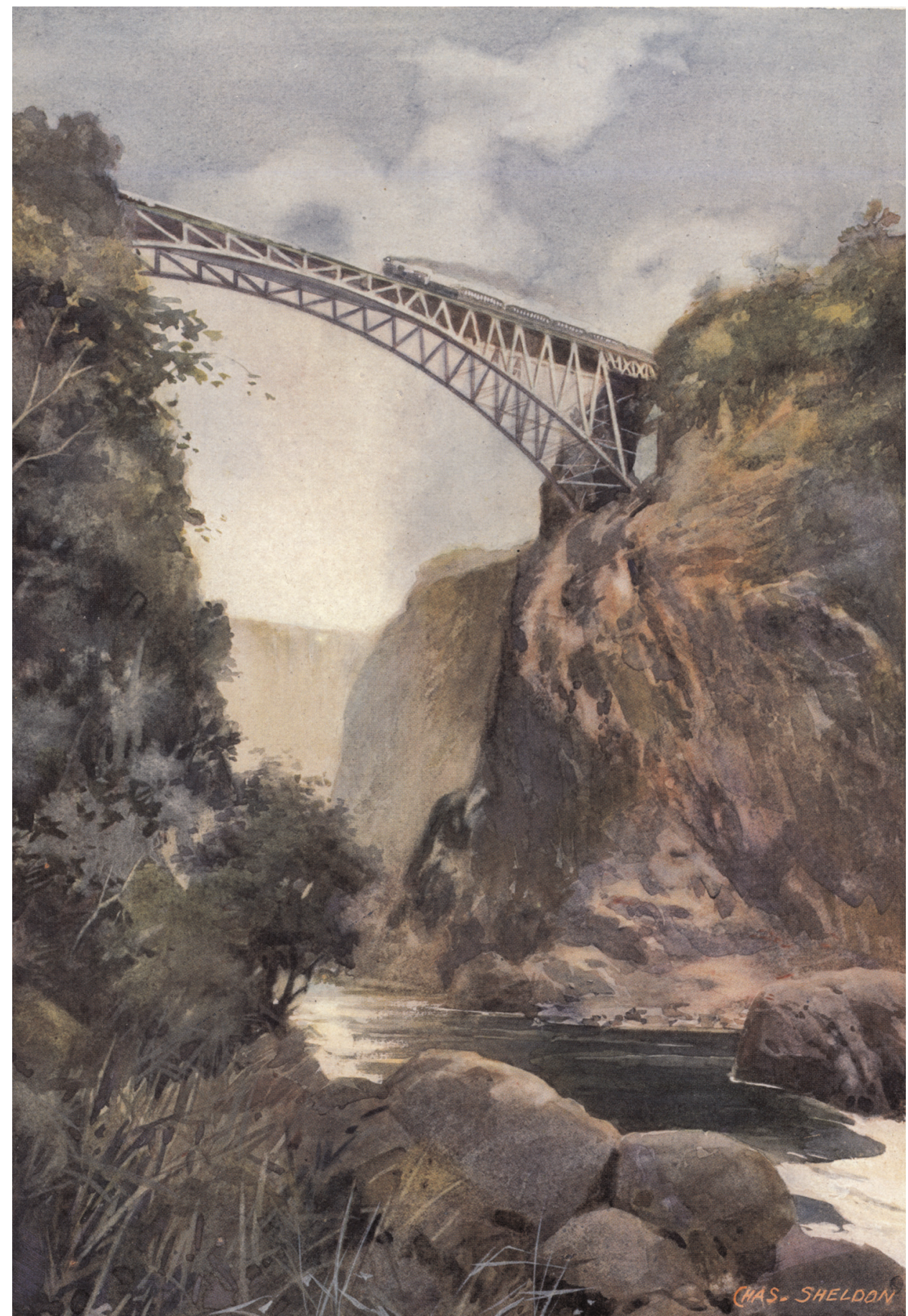




\section{Biographical Dictionary of Civil Engineers in Great Britain and Ireland}

\section{Volume 3: 1890-1920}

Edited by:

M. M. Chrimes

R. C. Cox

P. S. M. Cross-Rudkin

J. M. H. Elton

B. L. Hurst

R. C. McWilliam

R. W. Rennison

R. J. M. Sutherland

R. E. Thomas 
Full details of ICE Publishing sales representatives and distributors can be found at: www.icevirtuallibrary.com/info/printbooksales

Other titles by ICE Publishing:

The Civil Engineers: The Story of the Institution of Civil Engineers and the People Who Made It.

$\mathrm{H}$. Ferguson and M. Chrimes.

ISBN 978-0-7277-4143-1

The Contractors: The Story of British Civil Engineering Contractors.

$\mathrm{H}$. Ferguson and M. Chrimes.

ISBN: 978-0727758309

www.icevirtuallibrary.com

A catalogue record for this book is available from the British Library

ISBN 978-0-7277-5834-7

(C) ICE and Thomas Telford Limited 2014

ICE Publishing is a division of Thomas Telford Ltd, a wholly-owned subsidiary of the Institution of Civil Engineers (ICE).

All rights, including translation, reserved. Except as permitted by the Copyright, Designs and Patents Act 1988, no part of this publication may be reproduced, stored in a retrieval system or transmitted in any form or by any means, electronic, mechanical, photocopying or otherwise, without the prior written permission of the Publisher, ICE Publishing, One Great George Street, Westminster, London SW1P 3AA.

This book is published on the understanding that the authors are solely responsible for the statements made and opinions expressed in it and that its publication does not necessarily imply that such statements and/or opinions are or reflect the views or opinions of the publishers. Whilst every effort has been made to ensure that the statements made and the opinions expressed in this publication provide a safe and accurate guide, no liability or responsibility can be accepted in this respect by the author or publishers.

Whilst every reasonable effort has been undertaken by the author and the publisher to acknowledge copyright on material reproduced, if there has been an oversight please contact the publisher and we will endeavour to correct this upon a reprint.

Commissioning Editor: Jo Squires

Production Editor: Tamsin Cousins

Market Development Executive: Catherine de Gatacre

Typeset by Academic + Technical, Bristol

Indexes created by Indexing Specialists (UK) Ltd and Academic + Technical

Printed and bound by TJ International, Padstow 


\section{Contents}

Preface ............................ vii

Notes ............................ xi

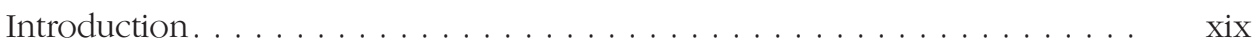

Biographical dictionary . . . . . . . . . . . . . . . . . . . . 1

Index of people . . . . . . . . . . . . . . . . . . . . . . . . . . 687

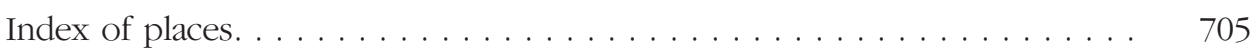




\section{Preface}

It is 20 years since the Archives Panel of the Institution of Civil Engineers initiated the compilation of a Biographical Dictionary of Civil Engineers. It was seen as answering a need within the profession and filling a gap in the published history of Great Britain and Ireland. The Council of the Institution agreed to support the enterprise. An Editorial Board, reporting to the Archives Panel, was appointed in May 1996.

Biographical works dealing with related professions were already well established notably by Sir Howard Colvin's Biographical Dictionary of British Architects, 1600 to 1840 (3rd edn. 1995; 4th ed. 2008) and Sarah Bendall's Dictionary of Land Surveyors of Great Britain and Ireland 1530-1850 (1997) developed from the earlier work edited by Peter Eden (1975-1979). Since then further works have followed by RIBA, and dictionaries of Irish and Scottish architects, and Irish County surveyors, all indicative of a demand for such compendia and the need to ensure ease of reference to the contribution of individual civil engineers to the creation of the infrastructure of Great Britain and Ireland, and many other parts of the world, if the profession is to be adequately acknowledged by history.

It was recognised that to satisfy these requirements would be impractical in a single volume, and the editorial board determined on three volumes to provide a combined reference source for the period 1500-1920. The first volume, covering the period 1500-1830, encompassed the origins of the profession, and the classic era of Smeaton, Rennie and Telford; the second volume, covering 1830-1890, saw the rapid expansion of the profession in the railway age, and the development of new engineering specialisms. This, the intended final volume covering the years 1890-1920, is consistent with what might be considered the birth of the modern age of civil engineering - with reinforced concrete and steel established as structural materials of choice, electrical power and the internal combustion engine increasingly shaping the built environment and the work of the profession, and the establishment by ICE of a qualification system for civil engineers that would be largely familiar a century later. Thereafter it was felt we would intrude into the memories of living people, and the rise of corporate design teams and limited companies made placing individual credit for works, a major element of the scope of these biographies, all but impossible. Alternative means of recording the last century are being looked at by the Archives Panel, including oral history techniques, whilst major initiatives like the Concrete and Motorway archives have captured major works of the past century.

Inevitably, and sadly, the personnel of the editorial board have changed over such a long period. Of the original editorial board, the chairman, Professor Sir Alec Skempton, died before the publication of the first volume, although the project remains very much true to his vision and inspiration. Board members Dr R. W. Rennison and Mr R. J. M. Sutherland died while this third volume was in progress. In both cases they had ensured they had completed their contributions before their respective deaths. 
This volume is dedicated to the memory of Bob Rennison and James Sutherland who both made significant and lifelong contributions to the scholarship of the history of civil engineering. Latterly their major effort has been to see through to completion the Biographical Dictionary of Civil Engineers project. Dr Rennison established a high standard of editorial consistency for contributions and James Sutherland ensured that all of his colleagues sought out the human stories that take these lives beyond the confines of engineering curriculum vitae. This volume marks a fitting epitaph to the careers of two great civil engineers of the late twentieth century.

The membership of the Editorial Board since its inception is recorded in the table below.

Dr M. R. Bailey

Mr M. M. Chrimes MBE

Dr R. Cox

Mr P. S. M. Cross-Rudkin

Miss J. M. H. Elton

Mr B. L. Hurst

Dr R. C. McWilliam

Dr R. W. Rennison

Mr E. C. Ruddock MBE

Professor Sir Alec

Skempton

Mr R. J. M. Sutherland

Mr T. Swailes

Mr R. E. Thomas

\section{Affiliation}

Altrincham

Institution of Civil Engineers

Trinity College, Dublin

Coventry University and Castor

London

Hurst Peirce and Malcolm

Reading and Edinburgh

Newcastle-upon-Tyne

Edinburgh

Imperial College London

London

University of Manchester

Institution of Structural

Engineers

$\begin{array}{lll}\text { Volume 1 } & \text { Volume } 2 & \text { Volume 3 } \\ \text { Contributor } & \text { EB } & \\ \text { Secretary } & \text { Secretary } & \text { Secretary } \\ \text { EB } & \text { EB } & \text { EB } \\ \text { EB } & \text { Chair } & \text { EB } \\ & \text { Contributor } & \text { EB } \\ & \text { EB } & \text { EB } \\ & \text { EB } & \text { Chair } \\ \text { EB } & \text { EB } & \text { EB } \\ \text { EB } & \text { EB } & \\ \text { Chair } & & \\ \text { Contributor } & \text { EB } & \text { EB } \\ & \text { EB } & \\ & & \text { EB }\end{array}$

Their work has been supplemented by the expertise of a range of other specialist contributors whose names are appended to the articles they have written. The Editors have been ably supported by the staff of the Institution of Civil Engineers. Claire Delgal and Carol Morgan assisted in archival research. Valerie Lawless and Paul Parkes provided administrative support. Jo Squires and Tamsin Cousins of ICE Publishing saw this volume through to publication.

The present volume, like its predecessors, contains biographies of individuals engaged in civil engineering in Great Britain and Ireland. Engineers of British birth working overseas are included, as are some individuals, notably of Indian birth, who spent most of their careers overseas but whose work must be seen as part of an Anglo-Irish diaspora, rather than part of the history of the creation of new states. Generally those engineers born in what might be considered the great British dominions have been excluded unless they had a close relationship with the Institution or, like Sir John Monash, made a singular contribution to the fate of the British Empire.

This is a period when the definition of who might be considered a civil engineer becomes clear, but the Institution itself, through its desire to show leadership across the engineering profession, embraced in its leadership the professions of mechanical, metallurgical, and electrical engineering, and naval architecture. Leading practitioners in those areas are on occasion included. More perhaps could have been but most have their place already in the Oxford Dictionary of National Biography.

Research is ongoing, and inevitably there have been errors and omissions. Comments and contributions should be passed to the archivist at the Institution of Civil Engineers. The intention now is to supplement the printed volumes with a 
website. Corrections and updates will be provided in the December issues of the Panel for Historical Engineering Works newsletter which can be obtained through the library@ice.org.uk.

Mike Chrimes

Ron Cox

Peter Cross-Rudkin

Julia Elton

Lawrance Hurst

Bob McWilliam

Rob Thomas 


\section{Notes}

\section{Place names}

Names of the traditional British counties have been retained, as they represent the situation that existed at the period covered by this volume. Because very often the titles of clients commissioning civil engineering works contained contemporary geographical terms, place names are generally given as they were at the time. Where these names have changed, the modern name is given in brackets. The Dominion of Canada was not created until 1867 and the Commonwealth of Australia and the Union of South Africa until after 1890, so the names of the separate colonies are used. Generally usage of Indian names has followed contemporary rather than present day spelling in the text.

\section{Sources}

Use has been made of some sources that are generally not listed at the ends of the articles. These include:

Frank Smith files on contractors, at ICE archives

website Ancestry.com

Lawrence Popplewell, A Gazetteer of (the) Railway Contractors and Engineers (10 parts, listed regionally)

The published record of the Institution of Civil Engineers was called the Transactions, then the Minutes of Proceedings, then the Journal and most recently Proceedings.

\section{Publications}

Lists of publications are only given for subjects whose main contribution to civil engineering was through their research or authorship.

\section{Patents}

Lists of patents are only given for subjects whose main contribution to civil engineering was through their research and development.

\section{Works}

Generally, only major works actually constructed are listed.

Out-turn prices for contracts can differ significantly from tender prices. It is not always clear from sources whether values stated are one or the other.

\section{Cross references}

Asterisks are used to cross reference to other articles in the Dictionary. One asterisk is used for articles in Volume 1 (1500-1830), two for Volume 2 (1830-1890) and three for Volume 3 (1890-1920). The asterisks are usually placed before the family name of the subject, but where two members of the same family, each with a separate article, 
are mentioned together, the asterisks are placed after their respective first names e. $\mathrm{g}$. George $^{* *}$ and Robert ${ }^{* *}$ Stephenson.

\section{Honours}

Several leading civil engineers were knighted. Where they are mentioned in a context that precedes the award, the title is given in parentheses.

\section{Conversion of units}

Weights and measures are given in their original (Imperial system) units. Metric equivalents are:
Length
1 inch (in.) $=25.4$ millimetres
1 foot $(\mathrm{ft})=.12 \mathrm{in} .=0.305$ metre
1 yard $=3 \mathrm{ft}$. $=0.914$ metre
1 mile $(1760$ yards $)=1.609$ kilometres

\section{Area \\ 1 acre (4840 sq. yards) $=0.405$ hectare \\ Volume \\ 1 gallon $=4.55$ litres \\ $1 \mathrm{cu}$. ft. $=0.0283$ cubic metre \\ $1 \mathrm{cu}$. yards $=0.765$ cubic metre}

1 square inch (sq. in.) $=645$ square millimetres

1 square foot $(\mathrm{sq} . \mathrm{ft}$. $)=0.0930$ square metre

1 square mile $=640$ acres $=259$ hectares

\section{Mass}

1 pound $(1 \mathrm{~b})=.4.45 \mathrm{~N}=0.454$ kilogram

1 ton $(2240 \mathrm{lb}$. $)=9.97 \mathrm{~N}=1.016$ tonnes

\section{Pressure}

1 pound per sq. in. (psi or $\left.\mathrm{lb} / \mathrm{in}^{2}{ }^{2}\right)=6.90 \mathrm{kN} / \mathrm{m}^{2}=0.070 \mathrm{~kg} / \mathrm{m}^{2}$

1 ton per sq. ft. $=107 \mathrm{kN} / \mathrm{m}^{2}=1.09 \mathrm{~kg} / \mathrm{cm}^{2}$

\section{Power}

1 horsepower $(\mathrm{hp})=0.746$ kilowatt

\section{Currency}

Up to 1971 the English pound sterling was divided into shillings and pence:

1 shilling $(\mathrm{s})=12$ pence $(\mathrm{d})$

1 pound $(£)=20$ shillings

1 guinea $=21$ shillings $=£ 1.05$

\section{Membership of the Institution of Civil Engineers}

As mentioned in the introduction, the Institution of Civil Engineers was divided from the start into different classes, that changed from time to time. In the period under review, Members were the senior class and from 1878 Associate Members formed a junior class, but only these two had full voting rights. To differentiate them from the corresponding classes of membership introduced in 1968, Fellows and Members, the following abbreviations have been used:

MInstCE Member of the Institution of Civil Engineers

AMInstCE Associate Member of the Institution of Civil Engineers 
The other senior class was:

AICE Associate of the Institution of Civil Engineers

\section{Abbreviations}

$A C E$

$A D B$

AJ

$A R$

Arch

ASCE Trans

Beesley

BAProc

BDCE1

BDCE2

Bingham

BJ

Bldr

BldgN

Boase

$B O D$

BriAssGasMan

BurmaEngCon

CambPhilSocTrans

CBEP

CECE

CEAJ

CESOAf

CIPATA

CITEN

ClevIE

CMES

Const hist

CSCE

CSCET

Cumming

DAASTrans

$D B B$

$D C B$

$D I A$

$D I B$

$D N Z B$

$D S A B$

$D S B B$

ECSMFE
Association of Consulting Engineers

Australian Dictionary of (National) Biography

Architects journal

Architectural Review

Architect

Transactions of the American Society of Civil Engineers

Gerard Beesley. Biographical Dictionary of Irish Railway

Engineers (in preparation)

British Association for the Advancement of Science Proceedings

Biographical Dictionary of Civil Engineers of Great Britain and Ireland, Volume 1, 1500-1830

Biographical Dictionary of Civil Engineers of Great Britain and Ireland, Volume 2, 1830-1890

Bingham, P. M. History of the Public Works Department, Ceylon, 1796-1913. 1921-1923. 3 volumes

Builders Journal

The Builder

Building News

Frederick Boase, Modern English Biography (1901, reprinted 1965), six volumes

O’Donoghue, B. The Irish County Surveyors. 1834-1946. 2007

Transactions, British Association of Gas Managers

Burma Engineering Congress

Cambridge Philsophical Society Transactions

Catalogue of British Engraved Portraits

Concrete and Constructional Engineering

Civil Engineer's and Architect's Journal

Civil Engineer in South Africa

Chartered Institute of Patent Agents

Concrete Institute Transactions and Notes

Cleveland Institution of Engineers

Civil and Mechanical Engineers Society

Construction History

Canadian Society of Civil Engineers

Transactions, Canadian Society of Civil Engineers

Cumming, D. A. and Moxham, G. They built South Australia. 1986

Devonshire Association for Advancement of Science

Transactions

Dictionary of Business Biography

Dictionary of Canadian Biography

Dictionary of Irish Architects

Dictionary of Irish Biography

Dictionary of New Zealand Biography

Dictionary of South African Biography

Dictionary of Scottish Business Biography

European Conference on Soil Mechanics and Foundation

Engineering 


\begin{tabular}{|c|c|}
\hline Elec & The Electrician \\
\hline$E N$ & Engineering News \\
\hline Engg & Engineering \\
\hline Engr & The Engineer \\
\hline$E N R$ & Engineering News Record \\
\hline$E R$ & Engineering Record \\
\hline ERev & The Electrical Review \\
\hline ESC & Engineering Standards Committee \\
\hline ESSP & Proceedings, Engineering Society of Shanghai (previously \\
\hline & Shanghai Society of Engineers and Architects and later \\
\hline & Engineering Society of China) \\
\hline Felstead & $\begin{array}{l}\text { Felstead, A., Franklin, J., and Pinfield, L. Directory of British } \\
\text { Architects 1834-1900. } 1993\end{array}$ \\
\hline FIMET & Transactions, (Federated) Institution of Mining Engineers \\
\hline Furkert & F W Furkert. Early New Zealand Engineers. 1953 \\
\hline GeolJ & Geological Journal \\
\hline Glas Her & Glasgow Herald \\
\hline Gray & $\begin{array}{l}\text { Gray, A. S. Edwardian architecture: a biographical dictionary. } \\
1980\end{array}$ \\
\hline GSIAJnl & Gloucestershire Society for Industrial Archaeology Journal \\
\hline Hist E tech & History and Technology \\
\hline Hist tech & History of Technology \\
\hline$I A R$ & Industrial Archaeology Review \\
\hline IATM & International Association for Testing Materials \\
\hline$I B$ & Irish Builder \\
\hline ICEJ & Journal, Institution of Civil Engineers \\
\hline$I E C$ & International Electrotechnical Commission \\
\hline IEEJ & Journal of the Institution of Electrical Engineers \\
\hline$I G E T$ & Transactions of the Institution of Gas Engineers \\
\hline$I L N$ & Illustrated London News \\
\hline ILOCOEJ & Journal of the Institution of Locomotive Engineers \\
\hline$I M J$ & Journal of the Institute of Metals \\
\hline IMCEprocs & $\begin{array}{l}\text { Proceedings of the Incorporated Association (later Institution) } \\
\text { of Municipal and County Engineers }\end{array}$ \\
\hline IMET & Transactions of the Institution of Mining Engineers \\
\hline$I M M T$ & Transactions of the Institution of Mining and Metallurgy \\
\hline IncGasInstTrans & Incorporated Gas Institute Transactions \\
\hline IndEngr & Indian Engineer \\
\hline IndEngg & Indian Engineering \\
\hline IndFEE & Indian and Far Eastern Engineer \\
\hline IPHEJ & Journal of the Institution of Public Health Engineers \\
\hline$I R C A$ & International Railway Congress Association \\
\hline ISIJ & Journal of the Iron and Steel Institute \\
\hline IWET & Transactions of the Institution of Water Engineers \\
\hline JnlAsSoc & Journal, Association Society, Bengal \\
\hline$J B H$ & Journal of Business History \\
\hline JChemSoc & Journal, Chemical Society \\
\hline$J G L$ & Journal of Gas Lighting, Water Supply and Sanitary Engineering \\
\hline JRoyAgSoc & Journal of the Royal Agricultural Society of England \\
\hline JnIIRRS & Journal, Irish Railway Record Society \\
\hline JnlLondonMathSoc & Journal, London Mathematical Society \\
\hline JnlRGS & Journal, Royal Geographical Society \\
\hline
\end{tabular}


$J T H$
LESJ
$M$ \& $M$

MAE T

MLEPS $p$

Marshall

MechE

MinJ

ModTrans

MinProcICE

NMRS

NEIES T

$N P L$

ODNB

PhilM (1)

PbilTrans

PIANC

PIARC

Pike (05)

Pike (08)

Pike (10)

PLB

PPIE

PrOCAMSE

ProcEngAssNSW

ProcIMechE

ProcRSEd

ProcRoySOC

PUnJEC

PWIJ

QuartinlGeolSoc

RCAHMS

(R)SanI

RCHS jnl

Rail Engr

Rail G(I)

Rail Mag

Rail N

Rail T

REJnl

RIA

RIBA

RIBA Trans
Journal of Transport History

Liverpool Engineering Society Journal

Statement exhibiting the Moral and Material Progress and Condition of India (annual - usually as an HC paper, occasionally a Cd or Cmd paper)

Transactions of the Manchester Association of Engineers

Proceedings of the Manchester Literary \& Philosophical Society

Marshall, John. Biographical Dictionary of Railway Engineers.

2 eds

Mechanical Engineering

Mining Journal

Modern Transport

Minutes of Proceedings of the Institution of Civil Engineers

National Monuments Record of Scotland

Transactions, North East Coast Institution of Engineers and

Shipbuilders

National Physical Laboratory

Oxford Dictionary of National Biography (formerly known as the new edition of the Dictionary of National Biography)

Philosophical Magazine (series)

Philosophical Transactions of the Royal Society of London

Permanent International Association of Navigation Congresses

Permanent International Association of Roads Congresses

Pike, W. T. London at the opening of the twentieth century. 1905

Pike, W. T. British Engineers and allied professions in the

twentieth century. 1908

Pike, W. T. British Engineers and allied professions in the

twentieth century. 1910

private letter book

Professional Papers Indian Engineering

Proceedings of the Association of Municipal and Sanitary

Engineers

Proceedings of the Engineering Association of New South Wales

Proceedings of the Institution of Mechanical Engineers

Proceedings of the Royal Society of Edinburgh

Proceedings of the Royal Society of London

Punjab Engineering Congress

Journal of the Permanent Way Institution

Quarterly Journal Geological Society

Royal Commission on the Ancient and Historical Monuments of Scotland

(Royal) Sanitary Institute

Journal of the Railway and Canal Historical Society

Railway Engineer

Railway Gazette (International)

Railway Magazine

Railway News

Railway Times

Royal Engineers Journal

Royal Irish Academy

Royal Institute of British Architects

(Royal) Institute of British Architects Transactions 


\begin{tabular}{|c|c|}
\hline RS Cat & Royal Society (London) Catalogue of Scientific Papers \\
\hline$R S A j$ & Journal of the Royal Society of Arts \\
\hline$R S E$ & Royal Society of Edinburgh \\
\hline RSH & Royal Society of Health \\
\hline SAICE & South African Institution of Civil Engineers \\
\hline Sandes & Sandes, E. W. C. The military engineer in India. 1933-1938 \\
\hline Sharp & Sharp, R. Obituaries of British Engineers 1901-1920 \\
\hline Singer (5) & History of Technology (vol. 5 , etc.) \\
\hline$S P$ & State Papers \\
\hline SWIE $p$ & South Wales Institute of Engineers Proceedings \\
\hline$T E C$ & Technology and Culture \\
\hline TIESS & $\begin{array}{l}\text { Transactions of the Institution of Engineers and Shipbuilders in } \\
\text { Scotland }\end{array}$ \\
\hline $\operatorname{Tram} W$ & Tramway World \\
\hline TransCWAAS & $\begin{array}{l}\text { Transactions of the Cumberland \& Westmoreland Antiquarian } \\
\text { and Archaeological Society }\end{array}$ \\
\hline TransICEI & Transactions of the Institution of Civil Engineers of Ireland \\
\hline TransNewcSoc & Transactions of the Newcomen Society \\
\hline $\operatorname{Trans}(R) I N A$ & Transactions of the (Royal) Institution of Naval Architects \\
\hline $\operatorname{Trans}(R) S A$ & Transactions of the (Royal) Society of Arts \\
\hline TranSocEng & Transactions of the Society of Engineers \\
\hline TransuSocEng & Transvaal Society of Engineers \\
\hline TSE & The Structural Engineer \\
\hline$U I C$ & International Union of Railways \\
\hline$V D I-Z$ & Verein Deutscher Ingenieur-Zeitschrift \\
\hline VicAssE & Victoria Association of Engineer \\
\hline$W W E$ & Water (and water engineering) \\
\hline$W w W(I / I I / I I I / I V)$ & Who was Who: a companion to Who's Who (Vols I, II, III or IV) \\
\hline $\mathrm{BL}$ & British Library \\
\hline BoT & Board of Trade \\
\hline BSI & British Standards Institution \\
\hline $\mathrm{Cd}$, Cmd & Command paper (pre-1919 Cd, post 1919 Cmd) \\
\hline CLRO & Corporation of London Record Office \\
\hline DSIR & Department of Scientific and Industrial Research \\
\hline GOI, PWD & Government of India, Public Works Department \\
\hline $\mathrm{HC}$ & House of Commons \\
\hline ICE & (the) Institution of Civil Engineers \\
\hline IEAust & (the) Institution of Engineers of Australia \\
\hline IESS & (the) Institution of Engineers and Shipbuilders of Scotland \\
\hline IMechE & (the) Institution of Mechanical Engineers \\
\hline IMunE & (the) Institution of Municipal Engineers \\
\hline IRB & India Railway Board \\
\hline ISD & India Store Depot \\
\hline IWPC & Institute of Water Pollution Control \\
\hline MoT & Ministry of Transport \\
\hline MWB & Metropolitan Water Board, London \\
\hline NA & National Archives, Kew \\
\hline NAS & National Archives of Scotland, Edinburgh \\
\hline NLI & National Library of Ireland, Dublin \\
\hline NLS & National Library of Scotland, Edinburgh \\
\hline NLW & National Library of Wales, Aberystwyth \\
\hline
\end{tabular}




$\begin{array}{ll}\text { OAC } & \begin{array}{l}\text { British Library Oriental Collections } \\ \text { OS }\end{array} \\ \text { PRONI } & \begin{array}{l}\text { Prdnance Survey } \\ \text { PWD }\end{array} \\ \text { RIA } & \begin{array}{l}\text { Public Wecord Office of Northern Ireland } \\ \text { Royal Irish Academy }\end{array} \\ \text { CB } & \text { Companion of the order of the Bath } \\ \text { CMG } & \text { Companion of the order of St Michael and St George } \\ \text { CSI } & \text { Companion of the order of the Star of India } \\ \text { DL } & \text { Deputy Lieutenant } \\ \text { FRS } & \text { Fellow of the Royal Society } \\ \text { FRSE } & \text { Fellow of the Royal Society of Edinburgh } \\ \text { JP } & \text { Justice of the Peace } \\ \text { jr } & \text { junior } \\ \text { MRIA } & \text { Member of the Royal Irish Academy } \\ \text { ms }(s) & \text { manuscript(s) } \\ \text { QC } & \text { Queen's Counsel } \\ \text { Revd } & \text { Reverend } \\ \text { Sr } & \text { senior }\end{array}$




\section{Introduction}

This Volume continues the pattern established in the two earlier biographical dictionaries. It provides basic biographical information on the lives, works and careers of individuals engaged in the practice of civil engineering whose careers flourished in the period 1890-1920. Volumes 1 and 2, covered the periods to 1830 and from 1830 to 1890 respectively. ${ }^{1,2}$ A small number of individuals whose career spanned the 1890 dividing line already have appeared in Volume 2. Individuals born after 1885 are generally not included unless they ceased to contribute to the profession before 1920.

The period covered by the third volume deals with the increasing scale, complexity and specialisation of British and Irish civil engineering endeavours within and beyond Great Britain and Ireland. National identity becomes more debatable. During the period covered Ireland was part of the United Kingdom, but some established careers followed into the Free State after 1922. Civil engineers, whose birthplace, education and formative years in the profession were abroad, sometimes relocated to the United Kingdom. Others who rendered enormous service to the infrastructure of the British Empire barely set foot there. Where their lives are the subject of established national biographies, such as those of Australia, New Zealand, South Africa and Canada, most have not been included. Notable exceptions are Jeb Bradfield and John Monash, the latter the most significant engineering contributor to the fighting forces in the Great War.

The style of the earlier volumes is retained as far as possible, but some changes have been required to reflect the attributes of this later period. It was tempting to assign the movement of engineering change to the more complex organisations themselves, but the more effort that was put into unscrambling the role of individuals from the organisational structure built around them the more often an individual's contribution was identified.

Most of the individuals named in these dictionaries are not named in other reference books. A few of the entries in this volume have been published in the 'Oxford Dictionary of National Biography' (ODNB), which succeeded the century old 'Dictionary of National Biography' as the national pantheon in 2004. Its initial 60 printed volumes are now becoming a smaller proportion of its increasing number of on-line entries, which may never be offered as a traditional printed book.

Engineering biography has different priorities from either the study of entrepreneurs or the selection of individuals for a national pantheon. These priorities arise from the long-life of many civil engineering works. This heritage makes it useful to both identify the major works of individuals and to establish the identities of their trainees. It is likely that trainees would be influenced by, if not follow, their mentor's approach to design in their own works. This is particularly important for works built before 1920 as design procedures had not begun to be standardised until World War I. ${ }^{3}$ Until then it had been the opinion of the Institution of Civil Engineers that such matters as the loads to be borne by new bridges were the decision of their sponsors and did not 
need to be the subject of any national consensus. ${ }^{4}$ Those who maintained that legacy began to become as important in this period as the creators of new works.

\section{ICE Building at 25 Great George Street on the occasion of the Coronation of Edward VII}

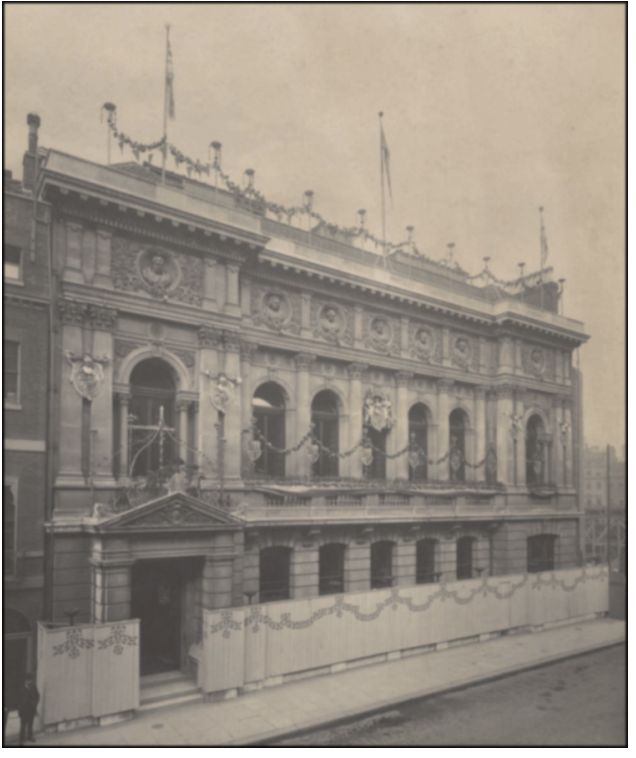

The building, designed by Charles Barry Jr was to be demolished and replaced by the present building, designed by James ${ }^{* * *}$ Miller at 1-7 Great George Street, 1910-1913

During 1890-1920 there were many subtle changes in the employment of civil engineers world-wide and of the significance of the Institution of Civil Engineers. It was the leading engineering society in Britain and was the model generally followed by other similar bodies in both the United Kingdom and elsewhere. More new members joined the ICE in those thirty years than in all the previous years combined since its formation in 1818. The Institution of Civil Engineers is a hierarchical organisation. At that time there were three main categories of member. Students were trainees of between eighteen and twenty-six years of age who were or had been pupils of a fully qualified member. Their numbers collapsed in the Great War and took a decade to recover. The largest group were Associate Members who were over twenty-five years old, who had both been trained as civil engineers and been engaged in civil engineering work for at least five years. The third main class was Members who were over the age of thirty and who had been employed as a resident engineer or equivalent for at least five years. Above these three layers was the select group of Members of Council. The Council expressed the Institution's official opinions as well as governed its operations and finances. 
Table 1: ICE membership growth (source: ICE records)

\begin{tabular}{|c|c|c|c|c|c|c|}
\hline & $\begin{array}{l}\text { Hon. } \\
\text { Members }\end{array}$ & Members & $\begin{array}{l}\text { Associate } \\
\text { Members }\end{array}$ & Associates & Students & Totals \\
\hline 1880 & 18 & 1209 & 1287 & 568 & 613 & 3695 \\
\hline 1890 & 19 & 1684 & 2768 & 432 & 969 & 5872 \\
\hline 1891 & 20 & 1743 & 2965 & 422 & 914 & 6064 \\
\hline 1892 & 18 & 1774 & 3177 & 402 & 868 & 6239 \\
\hline 1893 & 15 & 1810 & 3377 & 376 & 819 & 6397 \\
\hline 1894 & 20 & 1832 & 3557 & 357 & 791 & 6557 \\
\hline 1895 & 17 & 1862 & 3687 & 357 & 816 & 6739 \\
\hline 1896 & 20 & 1884 & 3788 & 357 & 877 & 6926 \\
\hline 1897 & 21 & 1936 & 3916 & 357 & 881 & 7111 \\
\hline 1898 & 20 & 1964 & 3924 & 357 & 947 & 7212 \\
\hline 1899 & 20 & 2004 & 3953 & 357 & 964 & 7298 \\
\hline 1900 & 19 & 2033 & 3989 & 357 & 1007 & 7405 \\
\hline 1901 & 19 & 2067 & 3990 & 357 & 971 & 7404 \\
\hline 1902 & 20 & 2111 & 3998 & 357 & 959 & 7445 \\
\hline 1903 & 16 & 2127 & 4031 & 357 & 1017 & 7548 \\
\hline 1904 & 19 & 2176 & 4050 & 357 & 1115 & 7717 \\
\hline 1905 & 20 & 2249 & 4117 & 357 & 1207 & 7950 \\
\hline 1906 & 20 & 2292 & 4187 & 357 & 1302 & 8158 \\
\hline 1907 & 19 & 2298 & 4332 & 357 & 1451 & 8457 \\
\hline 1908 & 19 & 2283 & 4457 & 357 & 1551 & 8667 \\
\hline 1909 & 20 & 2279 & 4592 & 357 & 1697 & 8945 \\
\hline 1910 & 19 & 2303 & 4709 & 357 & 1782 & 9170 \\
\hline 1911 & 17 & 2330 & 4682 & 357 & 1682 & 9248 \\
\hline 1912 & 19 & 2327 & 5007 & 357 & 1559 & 9269 \\
\hline 1913 & 19 & 2356 & 5087 & 357 & 1432 & 9251 \\
\hline 1914 & 18 & 2373 & 5205 & 357 & 1386 & 9339 \\
\hline 1915 & 18 & 2375 & 5352 & 357 & 1189 & 9291 \\
\hline 1916 & 19 & 2341 & 5380 & 357 & 956 & 9053 \\
\hline 1917 & 19 & 2295 & 5399 & 357 & 724 & 8794 \\
\hline 1918 & 17 & 2277 & 5504 & 357 & 547 & 8702 \\
\hline 1919 & 18 & 2272 & 5699 & 357 & 425 & 8771 \\
\hline 1920 & 19 & 2271 & 5847 & 357 & 489 & 8983 \\
\hline 1930 & 19 & 2313 & 6467 & 357 & 1600 & 10756 \\
\hline
\end{tabular}

An analysis by Hirose of applications for ICE membership in this period, which was coincident with the introduction of ICE examinations as part of its qualification process, reveals a rapid increase in numbers with engineering degrees or diplomas. They increased from 9\% in 1885-1886 to 44\% in 1913-1914..$^{5}$ This suggests the ICE's policy was addressing a common criticism, namely, that British engineers needed to improve their academic credentials. However, the ICE was only part of an increasingly fragmented profession, and at that time perhaps its elite. Total membership of the ICE in 1910 was closely followed by the Institution of Electrical Engineers (6218), and then the Institution of Mechanical Engineers (5583). While membership of the Mechanicals and Civils had almost doubled since 1890, that of the 
Electricals had trebled. The Institution of Mining and Metallurgy had grown from 615 members in 1900 to 2372 in 1914, whilst the UK coalfield based Institution of Mining Engineers had grown from 1239 to 3254 members 1890-1910.

Tables 2 and 3 categorise the ICE applicants in 1900-1901, and 1910-1911. In the decade 1900-1911 there is a modest decline in 'civil engineering' applications, a striking decline in the number of UK-based railway engineers, and an increase in electrical engineers. The appeal of ICE membership to those who had begun a career in the public sector, with its robust job market, career path and pension stands out, reflecting the growth in municipalisation since 1870, discussed further below. Both in the UK and overseas local authorities and state public works departments offered a variety of work, which would have included structural design, although most applications refer to public health and street improvements, refuse destructors, etc. Many consultants' works were also tied up with municipal provision. Private sector work comprised less than $40 \%$ of the total employment.

\section{Table 2: ICE Membership Applications in 1900-1901 (source: Hiroshi (2010); Chrimes (2012))}

\begin{tabular}{|c|c|c|}
\hline Civil engineers (general) & 75 & Some overseas \\
\hline Municipal engineers & $64^{*}$ & +3 electrical \\
\hline Railway engineers (UK) & 51 & Some mechanical \\
\hline Water engineers & $32^{*}$ & Some mechanical \\
\hline Structural engineers & 3 & \\
\hline Academics & 17 & Some non-civil \\
\hline Overseas (excluding general US) & & $27 \%$ \\
\hline PWD engineers & $67^{*}$ & Includes non-UK \\
\hline Railway engineers & $63^{*}$ & Includes non-UK, some public sector \\
\hline Total overseas & 130 & Underestimate \\
\hline Total civil engineers & 375 & \\
\hline \multicolumn{3}{|l|}{ Other disciplines } \\
\hline Electrical & 35 & $7 \%$ \\
\hline Mechanical & 25 & $5 \%$ \\
\hline Mining & 20 & $4 \%$ \\
\hline Gas & $13^{*}$ & Some public sector \\
\hline Shipbuilding & 10 & \\
\hline Iron and steel & 5 & \\
\hline Military & $2^{*}$ & \\
\hline Naval dockyards & $(8)^{*}$ & \\
\hline Chemical & 2 & \\
\hline Total other disciplines & 109 & $23 \%$ \\
\hline Total civil engineers & 375 & $77 \%$ \\
\hline Total applications & 484 & \\
\hline Total public sector* & 194 & $40 \%$ \\
\hline
\end{tabular}


Table 3: ICE Membership Applications in 1910-1911

(source: Hiroshi (2010); Chrimes (2012))

\begin{tabular}{|c|c|c|c|}
\hline Category & Numbers & Notes & Change since 1900 \\
\hline Civil engineers (general) & 92 & Some overseas & - \\
\hline Municipal engineers & 79 & +5 electrical & $=$ \\
\hline Railway engineers (UK) & 34 & +7 electrical & - \\
\hline Water engineers & 30 & Some public sector & - \\
\hline Structural engineers & 19 & 6. r. c. & + \\
\hline Academics & 19 & & - \\
\hline Overseas (excluding general ces) & & Underestimate & \\
\hline PWD engineers & 99 & Includes non-UK & + \\
\hline Railway engineers & 74 & Includes non-UK & - \\
\hline Total overseas & 173 & $28 \%$ & $(+)$ \\
\hline \multicolumn{4}{|l|}{ Other disciplines } \\
\hline Electrical engineers & 56 & $9 \%$ & + \\
\hline Mechanical engineers & 47 & $7.5 \%$ & + \\
\hline Mining engineers & 22 & $2.5 \%$ & - \\
\hline Gas engineers & 16 & Some public sector & $=$ \\
\hline Shipbuilding & 13 & & $=$ \\
\hline Iron and steel & 9 & & + \\
\hline Military & 4 & & $=$ \\
\hline Naval dockyards & 4 & & - \\
\hline Chemical & 3 & & $=$ \\
\hline Automobile & 2 & & + \\
\hline Total other disciplines & 176 & $28 \%$ & + \\
\hline Total civil engineers & 446 & $72 \%$ & - \\
\hline Total public sector & 270 & $43 \%$ & + \\
\hline Total applications & 622 & & + \\
\hline
\end{tabular}

After 1890 the distinctive feature of Britain's economy was not its manufacturing districts, which were individually challenged elsewhere. It was Britain's huge foreign investments that were different. ${ }^{6}$ The largest proportion, almost a third, of this investment was in mining. Despite a growing demand for qualified mining engineers, numbers of applicants to ICE from that sector dropped in the period. Although initially surprising given the willingness of new members to make their careers overseas it does indicate that the ICE was beginning to be less relevant for mining engineers.

More than half of the remainder of Britain's huge foreign investments was initiated by civil engineering such as railways, tramways, water supply, sewerage systems. The head offices of many of these overseas businesses were in London and their consulting engineers were there too. These were the figures that came to dominate the Council of the Institution of Civil Engineers which sat at the centre of a network that radiated far beyond its headquarters in Great George Street, Westminster.

The Institution had overseas members, almost from its founding. The former class of Corresponding or Non-Resident Members included all members living more than ten 


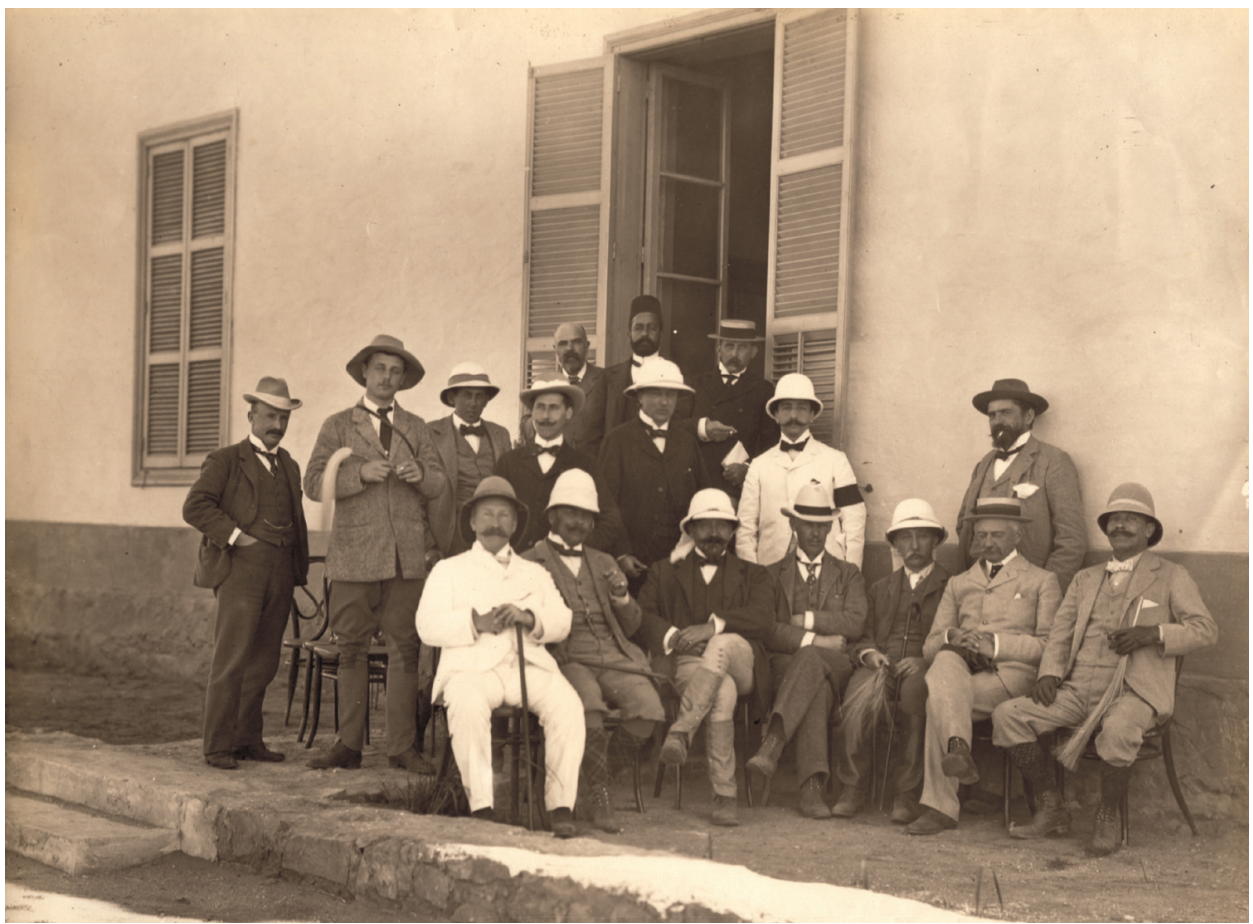

A group portrait of Aswan Dam Engineers, many of whom are mentioned in this work

miles from Westminster. By 1896 most of the ICE's membership would be more than ten miles from Westminster. Half the entire membership lived elsewhere in the United Kingdom. There were some connections with continental Europe, for example Professor Kapp, a reminder of Europe's belle époque, but more attention was given to developments in the United States. However the majority of the other members were within the British sphere of influence, such as India, Australasia, Canada and the colonies. Many applicants were born and educated in the Dominions, although this was less true for British India. British overseas links resulted in a steady trickle of significant local engineers admitted, such as the distinguished Chinese railway engineer, Jeme.

The ICE was more than an international learned society, it was also a London club for professional engineers. By the 1890s they had identified their own future with the growth of the British Empire and they saw centralised control from London as their key concern. ${ }^{7}$ When the ICE headquarters building was rebuilt in 1910 its imperial significance and identity was emphasised in the materials used for its construction which came from all parts of the Empire. It was intended to be as much a part of imperial Westminster as the nearby Colonial, Foreign and India Offices and included in its inner circles the senior engineering staff of the principal military departments.

The control sought by the Great George Street clique was not easily achieved. The overseas members expected some say in matters. They sought to influence the ICE so that their needs and requirements were addressed. They pushed for representation of specific expatriate constituencies on the ICE Council and for the setting up of local Advisory Committees. The small and highly influential group of Westminster-based consultants made concessions in order to retain and develop their connections with 


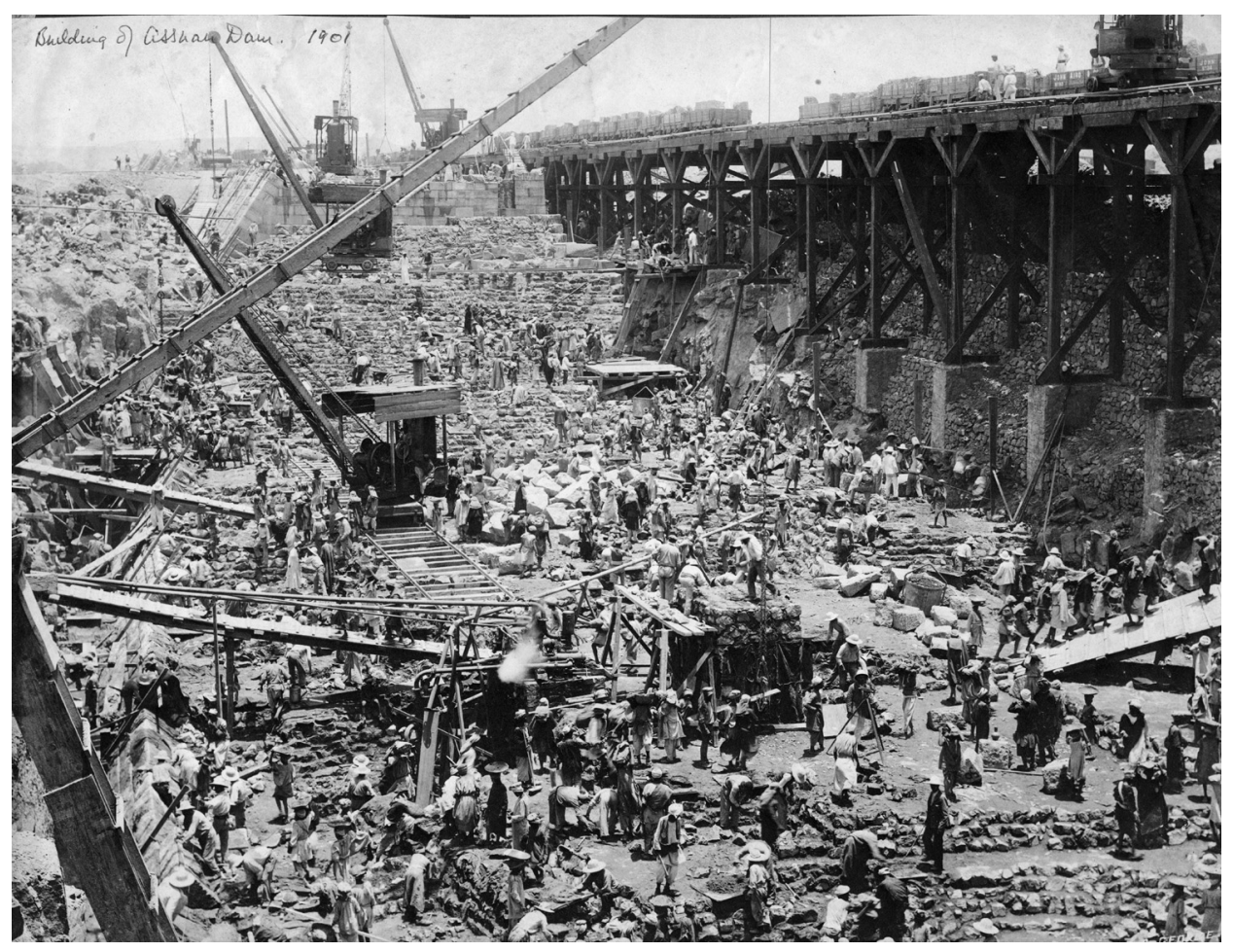

The building of the Aswan Dam 1901. Engineers: Sir William *** Garstin and Sir Benjamin *** Baker. Contractor: Sir John ${ }^{* * *}$ Aird

the diaspora of British and Irish engineers as people who could be called on with strong ties of friendship and obligation to help maintain their own power and authority. This imperialist view withstood and was perhaps reinforced by World War I. Less committed outsiders had already seen that the independent dominions would become increasingly so-no matter how much wishful-thinking was undertaken and minor concessions were offered in London. ${ }^{8}$ In the war's aftermath the leading ICE members would allow both the number of their lost sons and the significance of many of their temporary high offices to be offered as a reminder of their commitment to an imperial vision.

During the era covered by Volume 2 it was possible for a civil engineer to be both innovative in engineering science and make an impact in practical business at the same time. ${ }^{9}$ By the period considered in Volume 3 some early engineering researchers did move on to business, but only a small minority could be classed as innovators. Specialisation and segmentation around maturing technologies were the main trends of civil engineering - with only a few exceptions - in the period. Civil engineers, whose birthplace, education and formative years in the profession were abroad, sometimes relocated to the United Kingdom. Herbert Hoover, later to be a President of the United States, was based in London from 1900 until 1917 as a consultant mining engineer and merits a place in this volume as, contrary to the trend in his profession, he did submit an impressive application for ICE membership.

Membership of the Institution of Civil Engineers doubled over the thirty years under review and many members are worthy of at least a short mention, but membership is not a prerequisite for entry into the Biographical Dictionary of Civil Engineers. Also 
the heyday of the multi-discipline engineering institutions centred on the larger provincial cities occurred during this thirty years period. It is salutary to realise that of these once very active societies only one, the Glasgow-based Institution of Engineers and Shipbuilders in Scotland, continues to publish its transactions. The others were subsumed into the activities of the organisations, which later merged to become the Institute of Materials, Minerals and Mining (IOM3), whilst the regional activities of the ICE, IMechE and IET (formerly the Institution of Electrical Engineers) now cater for most of the other local engineering interests. Obituaries published in the ICE Minutes of Proceedings reduced dramatically in number during World War I and as result this valuable starting-point was not available for many potential entries in Volume 3. On the other hand in the twentieth century there were many more contemporary commercial publications, some of which identified individual responsibility while others include conflicting claims which required careful scrutiny by all involved in this Volume.

Individualistic civil engineering contractors, such as Aird, Arrol, Jackson, NortonGriffiths, Nuttall, and Pearson, were to have their last great fling before World War I. They were often as ingenious and perhaps more resourceful than the consulting engineers with whom they worked. Contractors were seldom represented on the ICE Council, but they were often much more adept at the practical transfer of technology and the organisations they established became a vital part of the national effort in World War I. Many pre-1920 civil engineers did not have university degrees, but academic awareness and theoretical analyses were increasing. This was the first period when engineering professors with full academic careers became ICE Presidents. There was an increased promulgation of engineering science through teaching and texts - a large increase in the publication of handbooks, such as the annual Kempe, and the emergence of publically available technical standards as part of a wider change in society and national infrastructure. This included a wider use of more rigorous testing and the beginning of government sponsorship of central laboratories. The first of these, the National Physical Laboratory, was controlled by the Royal Society with the support of, inter alia, the ICE. In 1916 the government set up the Department of Scientific and Industrial Research with a mandate to conduct research on subjects which concerned the community including building and encourage research by industry through research associations and the training of researchers in universities. Many ICE members were to participate in these activities.

These new approaches followed the introduction of new 'scientific' materials and their large scale exploitation. 1890 marked the completion of the Forth Railway Bridge. This project appeared in the careers of several entries in Volume 3, such as Arrol, Baker, Biggart, Cooper, Hunter, Middleton, Moir and Tuit, while the careers of some including Allan Duncan Stewart, Sir John Fowler and Sir William Siemens, whose steel was credited at the time with making it possible, are to be found in Volume 2. After 1890 rolled steel sections became the civil engineer's most used metal structural component. Another civil engineering use of steel was as reinforcement for concrete made with Portland cement. Portland cement became throughout the twentieth century the second most used processed material after treated water.

The use of concrete and steel in building, the traditional enclave of the architect, was to be a stumbling block for the ICE's Council. In 1900 the Royal Institute of British Architects requested the ICE's opinion on collaboration 'in design of certain classes of structure', the ICE response was that 'the practice of the Institution of acting independently in matters within its scope rendered it inadvisable for them to meet the wishes of the RIBA in this matter'. ${ }^{10}$ This attitude would lead to the establishment of the Concrete Institute and its successor the Institution of Structural Engineers, whose formation was another example of the then institutional proliferation in the British Engineering Profession'. ${ }^{11}$ The advent of concrete and steel also prompted architects 


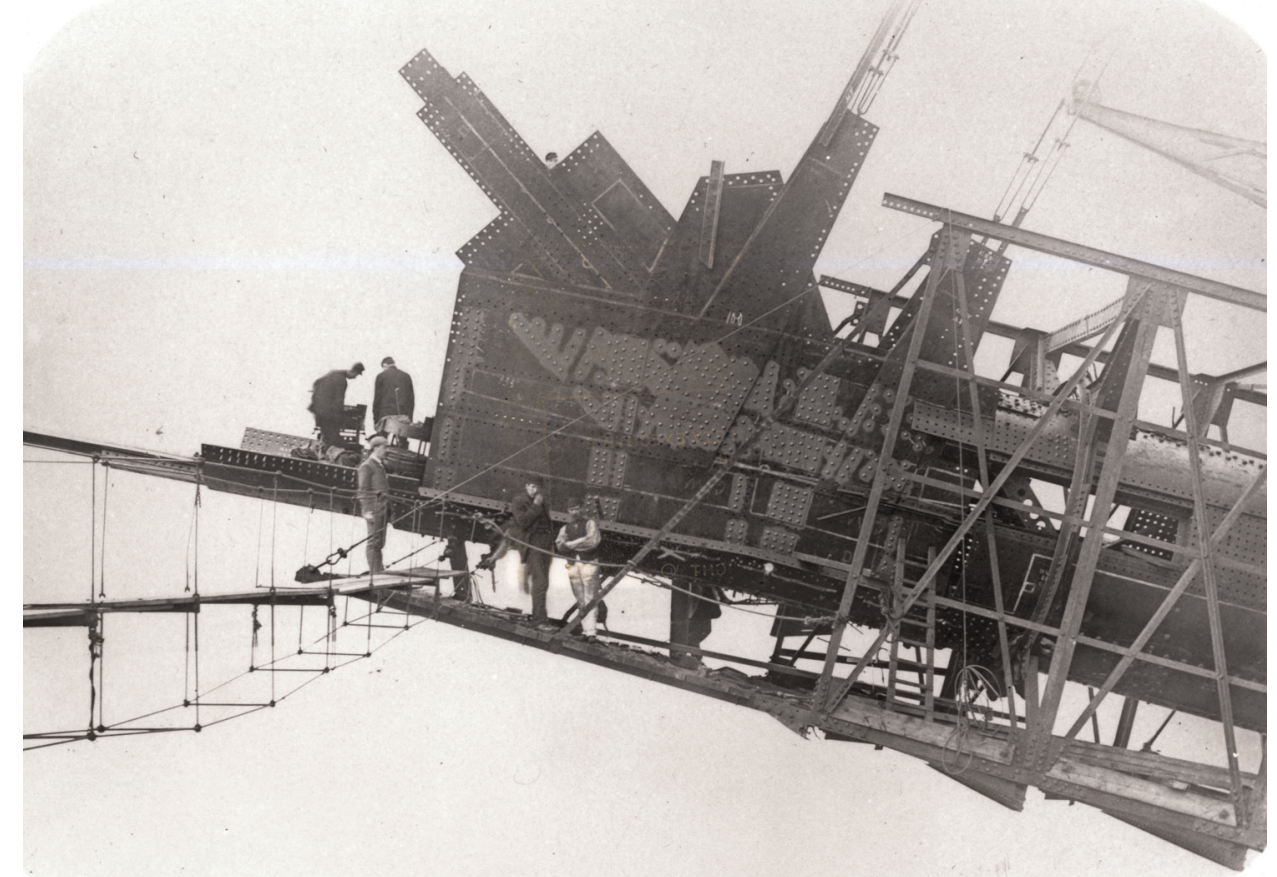

Construction of the Forth Bridge. Engineers: Sir John** Fowler and Sir Benjamin *** Baker. Contractors: ${ }^{* *}$ Tancred $^{* * *}$ Arrol and ${ }^{* *}$ Phillips

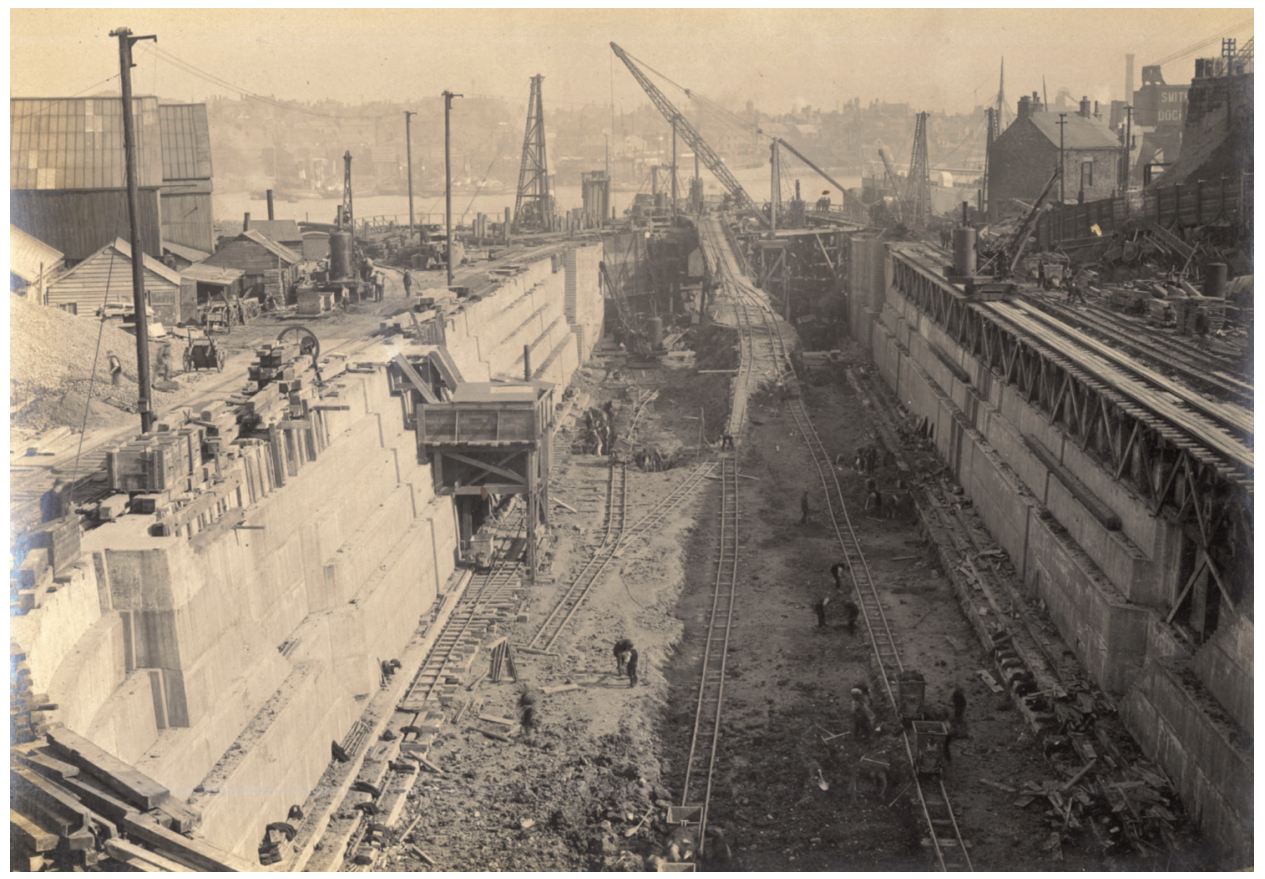

New graving Dock North Shields. Contractor: Sir John *** Aird 
to seek engineering assistance with the design of their buildings and the emergence of consulting engineers to provide such assistance, such as Bylander, Faber, Hurst and others. However, structural engineering, although increasing, remained numerically insignificant. The small number of readily identifiable structural engineers was initially almost exclusively involved in constructional steelwork. Structural design was undertaken by others, such as general civil engineers, railway engineers, even mechanical engineers involved in factory installation, but there is no evidence of it being a recognised career option. This may in part explain the initial indifference to the formation of the Concrete Institute in 1906-1908, the forerunner of the Institution of Structural Engineers. ${ }^{12}$ The extensive shared interests and personalities in concrete and steel technology result in all structural engineering activities being treated as part of civil engineering in this Volume.

Concrete and steel were also the materials that were to 'scale up the man-made world'. Larger docks and deeper navigation channels were required for much larger merchant ships as well as the larger warships of the naval race before 1914. These were complemented by rebuilding British railways for heavier and faster trains as well as more challenging bridge crossings. New routes were opened including the Great Central's main line into London, and the major improvements to the GWRs' main lines routes. A whole range of civil engineering techniques began to be developed or transferred from the mining industry to deal with new problems that were to arise in soil mechanics, foundations and temporary works. Some of these were prompted by the rapid development of London's tube network. The organisation of work especially the large-scale munitions projects required for the Great War was to tax many engineers and introduce more of them to the larger-scale of the process industries that marked the twentieth century.

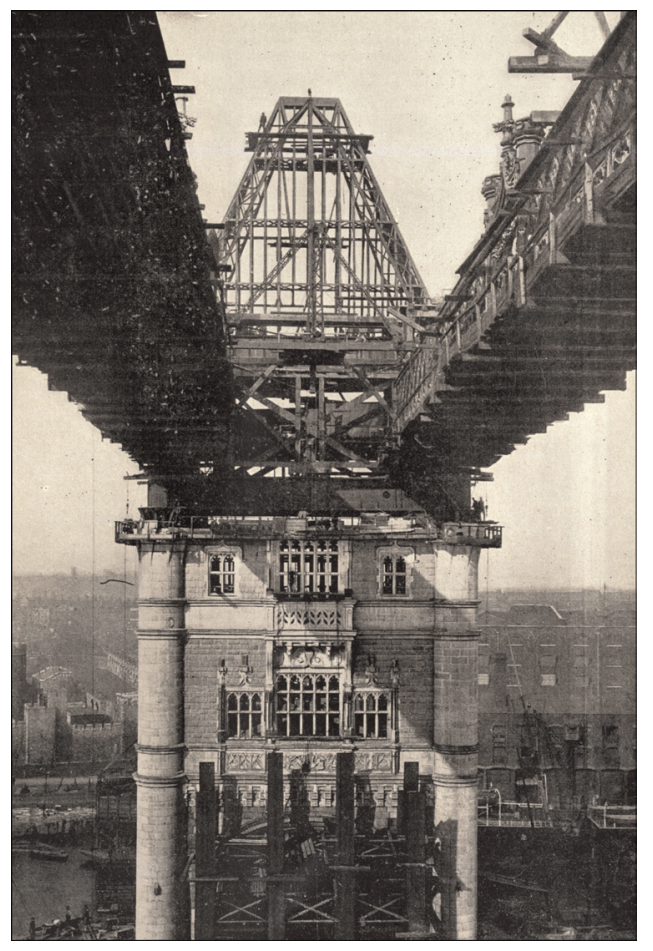

Tower Bridge under construction. Engineer: Sir John Wolfe *** Barry. Contractors: Sir William *** Arrol; Sir John *** Jackson 


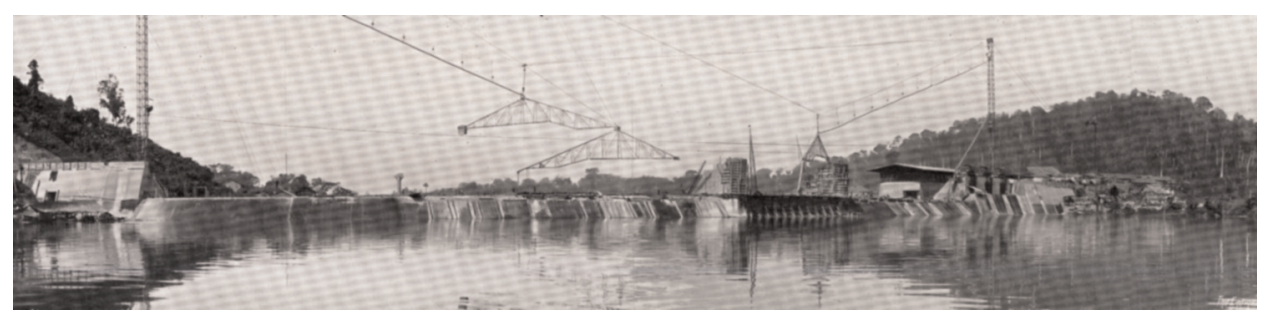

Perak River Hydroelectric Scheme. Contractors: *** Topham ${ }^{* * *}$ Jones and ${ }^{* * *}$ Railton

Before World War I the majority of Britain's huge foreign direct investments in railways, seaports, tramways, etc., employed civil engineers both as home-based consultants and overseas. There, especially in the British sphere of influence, bigger cities worldwide required large-scale utilities often financed by British capital. This extended beyond flood-control, water-supply, sewerage and town-gas, and included centralised electricity generation and distribution. The bulk of the infrastructure for the electric tramways was completed both abroad and in the UK during this period. Another device that began to impact on civil engineering was the motor car. Much was written about the 'dust nuisance' after the dry summer of 1905 and the techniques used to seal traditional surfaces. There is no shortage of notable civil engineers engaged in highways, for example Crompton, Hooley, Maybury, but it is harder to identify the pre-1920 mainstream civil engineering involvement with other new technologies such as aircraft and wireless.

The larger scale of heavy engineering projects after 1890 encouraged many distinguished engineers, whose core discipline was not or had ceased to be civil engineering to contribute to the ICE itself and would often serve as Members of Council. Many of these names appear in the 'Oxford Dictionary of National Biography', there being over one hundred whose entry refers to the ICE, but whose interesting lives do not include civil engineering works. Electrical engineering became one of the great growth industries in the period. At a senior level this is demonstrated by the decision of (Sir) Alexander Kennedy to switch from structural to electrical engineering. The number of marine engineers and naval architects appears remarkable nowadays with Yarrow, White, Watts, Thornycroft, Elgar, Hunter, Oram and Denny highly placed on the Council of ICE. A similar situation occurs with electrical engineers, such as Preece, Sankey, Snell and, perhaps more surprisingly, locomotive engineers, such as Aspinall, Dobson, Webb, as well as mechanical and steel industry specialists, such as Donaldson, Hadfield, Maw, Noble, Parsons, and Unwin.

Also in this period municipal engineering was evolving from its origins in sanitary science to deal with the problems arising from rapid urban growth. The term 'municipal enterprise' was coined. Municipal and County Engineers expanded their activities to include public housing, paving of streets and latterly the construction of new urban roads. Municipalisation saw the transfer of ownership of utilities from the private to public sector, either through 'democratic' municipal ownership or public bodies like the Metropolitan Water Board or Port of London Authority. The crossdisciplinary training of the municipal engineer enabled them both to plan and deliver. This branch of civil engineering introduced techniques, which later became the prerogative of the autonomous town planning profession. Their impact on urban development in the twentieth century was extensive. The successor body for these cross-disciplinary municipal engineers was the Institution of Municipal Engineers, which merged with the Institution of Civil Engineers in 1984, but its heyday was the early twentieth century. Interestingly the provision of 'public' services was one area 
to see inward investment with American capital involvement in electric tramways and the London tube network.

Many ambiguities seemed to have been tolerated throughout much of the period. Individual biographies present interesting examples. Provincial civil engineers, such as Aitken and Hooley, were able to have concurrent careers, serving more than one master, a 'moral hazard'-but a very effective way of transferring technology. ${ }^{13}$ The culture of the profession changed within that period and potential conflicts of interest became of greater concern to the public and members. The older members of the civil engineering profession fought a rear-guard action against this. Matters came to a head in 1911 when the 'young Turks' within ICE sought to establish what was to become the Association of Consulting Engineers. ${ }^{14}$ The group placed the aims and objects of the Association before ICE's Council and a deputation of mostly electrical specialists such as Alfred Herbert Dykes and J. F. C. Snell were subjected to hostile questioning.

The result was an open letter from the Institution of Civil Engineers which questioned the need for a distinction between a 'civil engineer' and a 'consulting engineer' The Council's main concern was that the Association would not accept anyone with a concurrent official position and this could in time 'exclude from advisory and consultative work engineers who hold official positions ....' whose experience may specially qualify them to give advice on matters with which they are conversant, would be an injustice to them and a serious loss to the public interest'. ${ }^{15}$ While the Association was concerned about competition for professional engineering work by persons who gained 'their principal emoluments from their commercial or manufacturing interests, and are on that account content to take low fees from consulting work'. ICE's Council formally informed the Board of Trade of their position when the

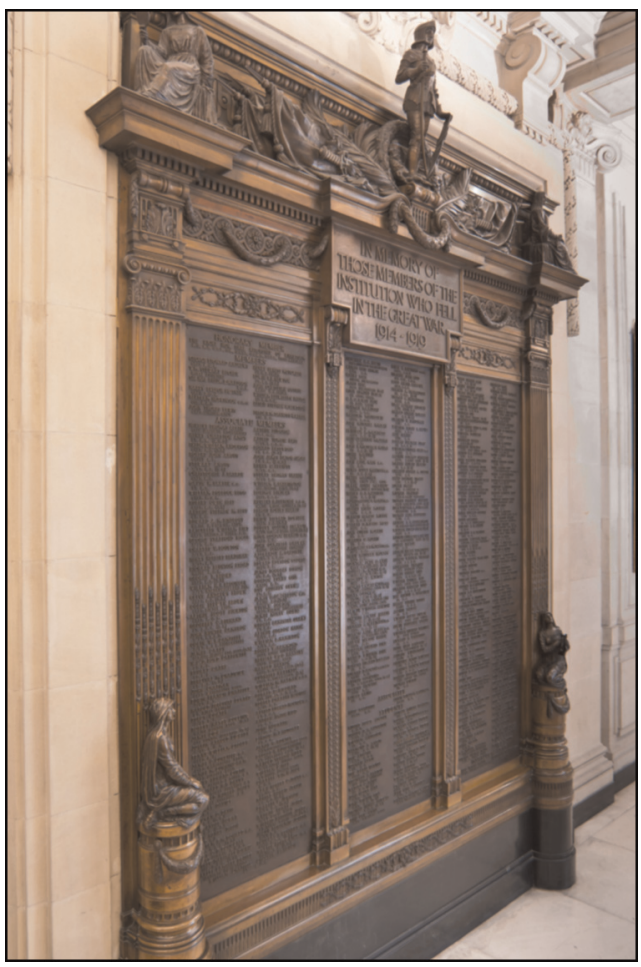

ICE Roll of Honour of those members who fell in the First World War, 1914-1919, First Floor, One Great George Street, Westminster 
Association of Consulting Engineers sought registration in 1912. In the event the Institution and the Association reconciled their differences within a generation and presented themselves as complementary bodies. ${ }^{16}$

1913 saw the completion of the Institution's headquarters building at One Great George Street, Westminster. Its architecture was chosen to reflect the prestige and authority of the profession. The building has been remarkably robust, continues to be owned by the ICE and, despite of inevitable modifications, continues to give the same image. ${ }^{17}$ Three thousand members of the Institution of Civil Engineers served in the armed forces during World War I and 343 perished. The Institution's Role of Honour, which lists those killed in the conflict, is re-produced opposite.

The motivational and other emotional aspects of the life and times of the civil engineers described here can never be fully told. It was before the era of recorded interviews. Their own writings were mostly either descriptive or promotional. Such information as does exist about the beginning of the twentieth century is only the chance survival of correspondence, official archives, newspapers and other publications. It is fortunate that such material survives at all-otherwise the salutary reminders of the contributions of individuals would be lost and with it the lessons to be learned from their trials and errors and subsequent achievements. A one-time mentor once cautioned: 'no matter how diligently you research you can never quite resurrect the dead'.

ROBERT C. MCWILLIAM

MIKE CHRIMES

1. Skempton, A. W. et al., 2002, A Biographical Dictionary of Civil Engineers in Great Britain and Ireland, vol. 1: 1500-1830, Thomas Telford, London.

2. Cross-Rudkin, P. S. M., and Chrimes, M. M., 2008, A Biographical Dictionary of Civil Engineers in Great Britain and Ireland, vol. 2: 1830-1890, Thomas Telford, London.

3. McWilliam, R. C. 2001, BSI: the first hundred years 1901-2001, Institution of Civil Engineers, London.

4. Council of the Institution of Civil Engineers 1910, Minute Book no. 20, p. 12 (20 December).

5. Hirose, S. 2010, Two Classes of British Engineers: an analysis of their education and training, 1880s-1930s. Technology and Culture, 51, 2: 388-402.

6. Corley, T. A. B. 1994, Britain's overseas investments in 1914 revisited, Business History, 36, 1: 71-88.

7. Andersen, C. 2011, British Engineers and Africa, 1875-1914, Pickering \& Chatto, London.

8. Constantine, S. 1992, Dominions Diary: the letters of E. J. Harding 1913-1916, Ryburn, Halifax.

9. Channell, D. F. 1982, The harmony of theory and practice: the engineering science of W. J. M. Rankine, Technology and Culture, 23, 1: 39-52.

10. Council of the Institution of Civil Engineers 1900, Minute Book no.15, item 800 (11 December).

11. Buchanan, R. A. 1985, Institutional proliferation in the British engineering profession, Economic History Review, new series, 38, 1: 42-60.

12. Witten, A. 2001, The Concrete Institute 1908-1923: precursor of the Institution of Structural Engineers, pp. 303-313, in Sutherland, R. J. M. et al. (eds.) Historic Concrete: the Background to Appraisal. ICE Publishing, London.

13. McWilliam, R. C. 2014, Transferring construction technology and conflicts of interest-a century ago, pp. 257-262, in Campbell, J. W. P. et al. (eds.) Proceedings of the First Conference of the Construction History Society, Queen's College, University of Cambridge, 11-12 April 2014.

14. Council of the Institution of Civil Engineers 1910, Minute Book no. 20, p. 116 (25 April). 
15. Council of the Institution of Civil Engineers 1911, Minute Book no. 20, p. 191 (28 October).

16. Watson, G. J. 1998, The Civils. Thomas Telford, London.

17. Dunkeld, M. 2013, One Great George Street: The Headquarters Building of the Institution of Civil Engineers, Whittles, Dunbeath, Caithness.

18. Chrimes, M. 2012, Short of education or short of engineers: British civil engineering 1890-1910. 4ICCH, Paris: Nuts and bolts construction history, 1, 575-586. 